\title{
Property Tax and Local Finance of Kosovo- An Overview
}

Submitted 25/04/19, 1st revision 17/05/19, 2nd revision 23/06/19, accepted 26/07/19

\author{
Gani Asllani ${ }^{1}$, Simon Grima ${ }^{2}$
}

\begin{abstract}
:
Purpose: In this article, we lay out the results of an analysis of the role of property tax regime in the local finance of Kosovo and highlight the current advantages and weaknesses.

Design/Methodology/Approach: We do this by carrying out an analysis of the legislation in force, which regulates financial issues at the central and local levels, the functioning of property tax, and other financial implications for municipalities. In doing this we review the level of dependence of municipalities on central government, grants and their share, as well as other issues which have an impact on fiscal decentralization. We also analyse tax system and its evolution, the participation of tax categories and municipality tax in central and local budgets and give specific accentuation to property taxation, role in the taxation system and local finances. Moreover, we present the institutional structures and their competencies, relationship between central and local institutions.

Findings: The current situation and system in place leaves much to be desired and property taxes may have more potential as a revenue source for municipalities.

Practical Implications: This article shows the importance for municipalities to find a means to self-finance through their own sources.

Originality/Value: We define needs for strengthening the Own Source Revenues (OSR), taking strong and coordinated steps to improve the management and collection of OSRs in general and property tax in particular.
\end{abstract}

Keywords: Local Finance, Self-Government, Property Tax, Fees and Charges, Own Source Revenue, Municipalities.

JEL Classification: F12, R11, R58.

Paper type: Commentary.

\footnotetext{
${ }^{1}$ Univesity "Haxhi Zeka", Departament of Finance, Law Faculty, Peja, Kosovo. E-mail: gani.asllani@unhz.eu

${ }^{2}$ University of Malta, Head, Department of Insurance, Faculty of Economics, Management and Accountancy, corresponding author, simon.grima@um.edu.mt
} 


\section{Introduction}

Since 1999, the republic of Kosovo has been under the United Nations administration, governed by the United Nations Mission in Kosovo (UNMIK) and the local Provisional Institutions of Self-Government, and security is provided by the NATO-led Kosovo Force (KFOR). Since May, 2001, UNMIK circulated the Constitutional Framework, which established the Provisional Institutions of SelfGovernment (PISG) in the Republic of Kosovo. Thereafter, UNMIK has gradually been transferring governing competencies to the PISG, although, they have maintained some powers which are normally carried out by sovereign states. On 17 February 2008, the Kosovo Assembly proclaimed the Independence of Kosovo, pursuant to the Ahtissari Package and under the supervision of the EULEX mission of the EU in Kosovo. After proclamation of Independence the reserved competencies where transformed to Kosovo Institutions. Actually, Kosovo has seven districts with 38 Municipalities.

Supported by the International Community, Kosovo created and is continuing to create its democratic institutions. Although progress has been made in many segments of economic and political life but there is still a need for further improvement and progress. In economic aspect Kosovo continues to build tax policies, oriented towards the market. These policies include building and implementation of modern concepts of taxation. This concept of taxation is in full compliance with international and EU regulations. The building and development of a taxation system (direct and indirect taxes) as well as other taxes at the central and local level are carried out for a relatively short period of time. Thus, in 1999, began the implementation of the UNMIK Customs Service Regulation (customs tax and excise), followed by the UNMIK Regulation No. 2000 / 45 on self-government of municipalities, the Regulation on Prejudged tax (May 2000), VAT (May 2001), Income tax (1 April 2002), Taxes on profit (2002), Property tax (June 2003), Corporate tax (2004), and others, including the application of other non-tax incomes at both central and local levels came into force.

At the central level, non-tax revenues are given specific importance with taxes related to using roads, royalty taxes, and different licenses for businesses (business registration), revenues from health, agriculture, transport education, travel documents and others at municipal levels by developing municipal regulations on fees, tariffs, charges and property tax. The functioning of local finances is certainly facing many problems and it requires finding adequate solutions.

\section{Literature review}

Property taxes belong to the oldest taxes of all. They were gradually replaced by income taxes and today, they represent only a complementary source of public revenues. These taxes, however, remain important as a revenue source for local governments (Kubátová and Vítek, 1997). 
The general property tax applies to all types of property in a uniform manner, regardless of the nature of the asset, its use or ownership. The property tax, deal with real estate tax or land tax (Malme, 2000). The selective property tax is imposed on a well-defined sub-set of property, mostly real estate property (Bell and Bowman, 1991). Property tax is a well-suited source of revenue for the local governments, which can serve as a local government's tool for fiscal autonomy of (Asllani, 2008).

There is no clear and common understanding of how property taxation influences the efficiency of land use (Trasberg, 2004). A few economists suggest that local property taxation promotes a households' efficient location and fiscal decisions (Oates, 1999). Therefore, real property taxes tend to distort private economic decisions less than other local taxes. On the other hand, economists view local property taxation as having a distorting effect on local decisions (Mieszkwoski and Zodrow, 1986). Therefore, such taxation tends to discourage improvements in the use of capital, land and property. The negative impact of property taxation is related also to the disproportionately greater administrative cost.

It is suggested in literature, that the identification of the appropriate tax base should be "a function of economic incidence and tax base volatility" (Musgrave \& Musgrave, 1989). Since the property tax is relatively stable and the burden is intended for those citizens who are financially better off, it satisfies these requirements. Therfore, proper administration of local real estate taxes is of direct positive influence on the success of decentralisation efforts in a country (Sedmihradská, 2010).

The only potentially significant and appropriate tax that the local government could assign is property tax. Although, far from being perfect, property tax is a good local tax (Bird et al., 1991), since it complies, with the requisits and characteristics of a good local tax. It is an "immobile tax base; sufficient, stable and predictable tax yield; reasonably fair or equitable; easy to administer; hard to export the tax burden to nonresidents; and the tax base is visible to ensure accountability". In fact, the property taxation supports the operational transformations of the local tax system (Felis, 2014).

\section{Methodology and Data}

For the purpose of this article and to define the current situation of how the Property tax system in Kosovo functions and its role in local finance; we carried out an analysis of secondary data sources, such as academic literature, the reports provided by the Ministry of Finance and international institutions, the Law on Property Tax, the Law on Bughet, the Law on Local Self Government, the Law on Local Government Finance and other available important statistical data.

\section{The Legal Aspect of Local Government and Finantial Sources}


The municipalities of Kosovo have two sources of finance available: own-source revenues and intergovernmental transfers. Municipalities are entitled to funding from the Central Authority. The Central Authority should notify municipalities in advance, for the next fiscal year, of the amount of the planned transfers to them. The Central Grant is a dominant revenue source for municipalities. The own-source revenues that municipalities are able to generate are insufficient to meet their needs. UNMIK was the first legal basis for the financial resources of municipalities regulation 2000 / 45. In 2004, the Working Group on Local Government creasted a Framework for the Reform of Local Self-Government in Kosovo, which was endorsed by the government. In the absence of a law for local finances, the Ministry of Economy and Finance (MEF) and the Ministry of Local Government, in cooperation with the Association of Municipalities, issued the Administrative Instruction No. 2007 / 2 by wherein there is the definition of own source revenues of the municipalities (fees and other municipality charges).

Based on this Regulation and Administrative Instruction issued by the respective Ministries, the Regulation for Municipalities no. 2007 / 30 was promulgated. This defines the competencies of municipalities and their institutional structure. After 2008, the Assembly of Kosovo has adopted several acts and approved two basic documents: Law on Local Self-Government (LAW NR. 03/L-040) and Law on Local Government Finance (LAW NO. 03/ L- 049). According to these Laws, the authority to manage budgets should be held by Municipalities as follows:

a) "All municipal services should be financed through municipal budgets which include own source revenues, central to local budgetary transfers, and extra budgetary funds";

b) "The authority is to set rates and exemptions for local taxes, fees, tariffs and fines, which should be guaranteed as a municipal prerogative although central authorities may set allowable rate ranges";

c) "Criteria that determine the allocation of grants to municipalities should be set by law";

e) "Municipal grant calculations should include measures to mitigate disparities among municipalities";

f) "A mandatory and consistent format for municipal budgets should be set by law";

g) "Municipalities should have the right to borrow in both internal and external capital markets in conformity with the Law on Public Financial Management and Accountability".

In Table 2, we present the level of the real estate tax in relation to the national tax system for the period 2015-2020. Property tax has exceptionally little importance, both in the national tax system and in local government revenues. As a whole, the Kosovar tax system is highly based on consumption taxes, namely VAT, excise and custom duties. The indirect taxes on consumption yield are much more important than direct taxes, and this tendency is becoming stronger, especially after the adoption of the new changes in Law on VAT, Excise Tax and other indirect tax. 
Table 1. Funding Sources for Municipalities

\begin{tabular}{|l|l|l|}
\hline Central Grant & Own-source revenues & \\
\hline $\begin{array}{l}\text { Inter-governmental } \\
\text { transfers }\end{array}$ & Fees and charges & Property Tax \\
\hline - Grant for & - Business License Fee & - House \\
administration & - Professional Business License Fee & - Apartment \\
- Specific Grant for & - Motor Vehicle Fee & - Commercial \\
object \\
Health & - Municipal Administrative Fees & - Industrial objects \\
- Specific Grant for & - Permit Fees for the Construction and & - Land and \\
Education & Demolition of Buildings and Other & - Others specific \\
- Grants for & Structures properties \\
enhanced & - Other Municipal Fees & \\
competencies & - Fees for Issuing Certificates and Official & categories \\
- Financing for & Documents & \\
CPC, QKHFZ and & - Charges, Rents, Fines and CoPayments & \\
KHM (social cases) & and Other Own Source Revenue & \\
- Financing from & -Regulatory Charges for Infrastructure - & \\
Borrowing & Development and Preservation & \\
& - Traffic Fines & \\
& - Fines for Offences against Municipal - & \\
Regulations & \\
\hline & - Rental Income & \\
\hline & - Education and Health Co-Payments & \\
\hline
\end{tabular}

Source: Adopted from treasury reports, Ministry Finance (2015-2020).

Table 2. Total budget revenues (budget and forecast) for period 2015-2020

\begin{tabular}{|l|l|l|l|l|l|l|}
\hline Description & $\mathbf{2 0 1 5}$ & $\mathbf{2 0 1 6}$ & $\mathbf{2 0 1 7}$ & $\begin{array}{l}\mathbf{2 0 1 8} \\
\text { Budget }\end{array}$ & $\begin{array}{l}\mathbf{2 0 1 9} \\
\text { Forecast }\end{array}$ & $\begin{array}{l}\mathbf{2 0 2 0} \\
\text { Forecast }\end{array}$ \\
\hline $\begin{array}{l}\text { I. TOTAL } \\
\text { REVENUE }\end{array}$ & $1,472.0$ & $1,596.5$ & $1,681.6$ & $1,816.9$ & $1,923.3$ & $2,032.7$ \\
\hline $\begin{array}{l}\text { 1.1. TAX } \\
\text { REVENUE }\end{array}$ & $1,269.0$ & $1,421.1$ & $1,495.7$ & $1,607.4$ & $1,710.1$ & $1,818.3$ \\
\hline Direct tax & 198 & 232.1 & 238.0 & 267.0 & 283.9 & 306.9 \\
\hline Tax debts & 0.0 & 0.0 & 0.0 & 0.0 & 0.0 & 0.0 \\
\hline $\begin{array}{l}\text { Tax on corporate } \\
\text { income }\end{array}$ & 68.0 & 80.8 & 75.3 & 84.2 & 90.1 & 98.3 \\
\hline $\begin{array}{l}\text { Tax on personal } \\
\text { income }\end{array}$ & 109 & 124.0 & 136.9 & 145.8 & 158.9 & 171.6 \\
\hline Property tax & 20.0 & 25.1 & 22.4 & 33.0 & 30.0 & 33.0 \\
\hline Other direct tax & 2.0 & 2.2 & 2.3 & 4.0 & 4.0 & 4.0 \\
\hline Indirect tax & 1,107 & $1,227.4$ & $1,315.2$ & $1,378.0$ & $1,471.2$ & $1,559.4$ \\
\hline Tax debts & 0.0 & 0.0 & 0.0 & 5.0 & 5.0 & 5.0 \\
\hline Value add Tax & 611.0 & 693.8 & 756.1 & 819.4 & 883.0 & 944.8 \\
\hline $\begin{array}{l}\text { Domestic } \\
\text { collection: }\end{array}$ & $/$ & 179.2 & 198.3 & 203.5 & 228.0 & 244.0 \\
\hline
\end{tabular}




\begin{tabular}{|c|c|c|c|c|c|c|}
\hline Border collection: & I & 514.6 & 557.6 & 615.9 & 655.0 & 700.9 \\
\hline Costumes duties & 131.0 & 130.0 & 126.0 & 111.0 & 108.0 & 100.0 \\
\hline Excise tax & 361 & 403.3 & 432.3 & 466.0 & 478.2 & 512.6 \\
\hline Other indirect tax & 3.0 & 0.4 & 0.8 & 2.0 & 2.0 & 2.0 \\
\hline $\begin{array}{l}\text { One-off revenues } \\
\text { from the collection } \\
\text { of tax debt }\end{array}$ & 0.0 & 0.0 & 0.0 & 4.0 & 5.0 & 4.0 \\
\hline $\begin{array}{l}\text { One-off revenue } \\
\text { from POE debt }\end{array}$ & 0.0 & 0.0 & 0.0 & 4.0 & 3.0 & 4.0 \\
\hline Tax refunds & -36.0 & -38.4 & -57.6 & -46.0 & -53.0 & -56.0 \\
\hline $\begin{array}{ll}\text { 1.2. } & \text { NON-TAX } \\
\text { REVENUES }\end{array}$ & 189 & 175.3 & 185.9 & 202.5 & 208.2 & 209.4 \\
\hline $\begin{array}{l}\text { Fees, charges, and } \\
\text { other from Central } \\
\text { Level BO-s }\end{array}$ & 85.0 & 92.4 & 103.4 & 100.0 & 103.0 & 103.2 \\
\hline $\begin{array}{l}\text { Fees, charges, and } \\
\text { other from Local } \\
\text { Level BO-s }\end{array}$ & 38.0 & 47.7 & 43.3 & 55.0 & 57.0 & 57.0 \\
\hline $\begin{array}{l}\text { Of which: the } \\
\text { revenues related to } \\
\text { waste tax }\end{array}$ & 0.0 & 0.0 & 0.0 & 0.0 & 7.0 & 7.0 \\
\hline Concessionary fees & 7.0 & 7.7 & 8.5 & 10.0 & 11.0 & 12.0 \\
\hline Mineral realty fees & 30.0 & 30.6 & 30.6 & 33.0 & 33.0 & 33.0 \\
\hline $\begin{array}{lr}\text { Revenue } & \text { from } \\
\text { mobile } & \text { network } \\
\text { license fess } & \\
\end{array}$ & 15.0 & 0.0 & 0.0 & 0.0 & 0.0 & 0.0 \\
\hline Dividends & 15.0 & 0.0 & 0.0 & 0.0 & 0.0 & 0.0 \\
\hline $\begin{array}{ll}\text { Income } & \text { from } \\
\text { interest } & \\
\end{array}$ & 0.0 & 0.0 & 0.0 & 4.5 & 4.2 & 4.2 \\
\hline
\end{tabular}

Source: Adopted from Medium Term Expenditure framework, 2019-2021. Ministry of Finance.

\section{Inter-governmental Fiscal Relations- Composition of LG Revenues}

In Table 3, we present the overall budget of central level, overall budget of municipalities; general grant of administration; health and education grant and finally own source revenues of the municipalities are presented. Dates are based on treasury reports and they represent facts ascertained during the budget planning. Dates are based on treasury reports and they represent facts ascertained during the budget planning, according to the revenues planned and transfers from previous years.

Table 3. Composition of $L G$ revenues - according to the planned budget in million EUROS (including grants)

\begin{tabular}{|l|l|l|l|l|l|l|}
\hline Description & $\mathbf{2 0 1 4}$ & $\mathbf{2 0 1 5}$ & $\mathbf{2 0 1 6}$ & $\mathbf{2 0 1 7}$ & $\mathbf{2 0 1 8}$ & $\mathbf{2 0 1 9}$ \\
\hline $\begin{array}{l}\text { Total National } \\
\text { Revenue }\end{array}$ & $1,345.00$ & $1,472.00$ & $1,596.50$ & $1,681.60$ & $1,816.90$ & $1,923.30$ \\
\hline
\end{tabular}




\begin{tabular}{|l|l|l|l|l|l|l|}
\hline $\begin{array}{l}\text { Total Municipal } \\
\text { Financing }\end{array}$ & 388.6 & 416.01 & 338.32 & 440.02 & 482.41 & 515.17 \\
\hline $\begin{array}{l}\text { 1. Government } \\
\text { Grants }\end{array}$ & 319.52 & 339.17 & 139.91 & 356.74 & 392.4 & 419.09 \\
\hline $\begin{array}{l}\text { General Grant } \\
\text { Base) }\end{array}$ & 137.57 & 145.76 & - & 149.2 & 173.6 & 180.69 \\
\hline General Grant & 127.8 & - & - & 145.2 & 168.92 & 175.79 \\
\hline $\begin{array}{l}\text { Contingency to the } \\
\text { correction formula }\end{array}$ & 9.77 & - & - & 4 & 4.68 & 4.9 \\
\hline Specific health grant & 39.9 & 42.08 & 42.08 & 44.11 & 48.5 & 53.4 \\
\hline $\begin{array}{l}\text { Specific Education } \\
\text { Grant }\end{array}$ & 142.56 & 151.33 & 161.63 & 163.43 & 170.3 & 185 \\
\hline $\begin{array}{l}\text { 2. Grants for } \\
\text { enhanced } \\
\text { competencies }\end{array}$ & 1.85 & 2.6 & 2.6 & 2.6 & 2.6 & 2.6 \\
\hline $\begin{array}{l}\text { Secondary health } \\
\text { care }\end{array}$ & - & - & - & 2.6 & 2.6 & 2.6 \\
\hline $\begin{array}{l}3 . \text { Residential } \\
\text { services }\end{array}$ & - & - & - & 1.62 & 1.65 & 1.62 \\
\hline $\begin{array}{l}\text { 4.Financing for } \\
\text { CEC, QKHEZ and } \\
\text { KHM }\end{array}$ & 0.24 & 0.24 & 0.24 & 0.06 & 0.06 & 0.06 \\
\hline $\begin{array}{l}\text { 5. Financing from } \\
\text { Borrowing }\end{array}$ & - & - & - & - & 3.7 & 4.8 \\
\hline $\begin{array}{l}\text { Municipal Own } \\
\text { Source Revenues }\end{array}$ & 67.23 & 74.24 & 80 & 79 & 82 & 87 \\
\hline $\begin{array}{l}\text { Fees and other } \\
\text { charges }\end{array}$ & 47.23 & 54.24 & 54.9 & 56.6 & 52 & 54 \\
\hline Property tax & 20 & 20 & 25.1 & 22.4 & 33 & 30 \\
\hline
\end{tabular}

Source: Adopted from the Department of Bughet, Ministry of Finance, 2019.

In Table 4, we present some important comparisons that show the dependence of municipalities from the central level, the participation of own source revenues in local budgets as well as other comperation for categories of revenues. From the table we can see that existe higer dependence from Central Bughet. Aslo, the participation of OSR are modest, and need for more strengthening and improvments.

Table 4. Percentage of local tax Budgeted

\begin{tabular}{|l|l|l|l|l|l|l|}
\hline Description & $\mathbf{2 0 1 4}$ & $\mathbf{2 0 1 5}$ & $\mathbf{2 0 1 6}$ & $\mathbf{2 0 1 7}$ & $\mathbf{2 0 1 8}$ & $\mathbf{2 0 1 9}$ \\
\hline $\begin{array}{l}\text { The central grants in } \\
\text { municipality budget }\end{array}$ & $82.7 \%$ & $82.1 \%$ & $76.3 \%$ & $82.0 \%$ & $83 \%$ & $83.1 \%$ \\
\hline $\begin{array}{l}\text { The municipality budget in } \\
\text { overall central budget }\end{array}$ & $28.9 \%$ & $28.3 \%$ & $21.2 \%$ & $26.2 \%$ & $26.6 \%$ & $26.8 \%$ \\
\hline
\end{tabular}




\begin{tabular}{|l|l|l|l|l|l|l|}
\hline $\begin{array}{l}\text { The own source revenues in } \\
\text { municipality budget }\end{array}$ & $17.3 \%$ & $17.8 \%$ & $23.6 \%$ & $17.9 \%$ & $17.0 \%$ & $16.8 \%$ \\
\hline $\begin{array}{l}\text { Fees and other charges on } \\
\text { total local revenues }\end{array}$ & $70.2 \%$ & $73.0 \%$ & $68.6 \%$ & $71.6 \%$ & $63.4 \%$ & $62.0 \%$ \\
\hline $\begin{array}{l}\text { Property tax as percentage } \\
\text { on total local tax revenues }\end{array}$ & $29.7 \%$ & $26.9 \%$ & $31.3 \%$ & $28.3 \%$ & $36.5 \%$ & $37.9 \%$ \\
\hline
\end{tabular}

Source: Adopted from Department of Budget, Ministry of Finance, 2019.

In Table 5, we present the total of own source revenue (OSRs), planned and realized revenues.

Table 5. Tax municipalities revenues, planned and those realised in Euro

\begin{tabular}{|l|l|l|l|l|l|}
\hline Description & 2013 & 2014 & 2015 & 2016 & 2017 \\
\hline Plane OSRs in Total & 63.00 & 67.23 & 74.24 & 80.00 & 79.00 \\
\hline Realized OSRs in Total & 56.10 & 59.80 & 57.16 & 68.49 & 66.10 \\
\hline \% realized & $89.0 \%$ & $88.9 \%$ & $76.9 \%$ & $85.6 \%$ & $83.6 \%$ \\
\hline $\begin{array}{l}\text { Planed revenues from Tariffs } \\
\text { and Charges }\end{array}$ & 44.9 & 47.23 & 54.20 & 54.9 & 56.6 \\
\hline $\begin{array}{l}\text { Realized revenues from Tariffs } \\
\text { and Charges }\end{array}$ & 39.7 & 38.1 & 36.86 & 45.79 & 42.4 \\
\hline \% realized & $88.4 \%$ & $80.66 \%$ & $67.95 \%$ & $83.40 \%$ & $74.91 \%$ \\
\hline $\begin{array}{l}\text { Planed revenues from Property } \\
\text { Tax }\end{array}$ & 18.1 & 20 & 20 & 25.1 & 22.4 \\
\hline $\begin{array}{l}\text { Realized revenues from } \\
\text { Property Tax } \\
\% \text { realized }\end{array}$ & 16.4 & 21.7 & 20.3 & 22.7 & 23.7 \\
\hline
\end{tabular}

Source: Adopted from Ministry of Finance reports, (2014-2019).

\section{Property Tax Procedure}

Prior to implementing the property tax, a pilot study was carried out (a project funded by USAID), based on UNMIK Regulation 2001/2, which regulation was in force until the new regulation was issued, that is, Property taxation nr. 2003/29, by the Assembly of Kosovo and promulgated by UNMIK, on 2012 which changed the Law NR. 04/L-100, which remained in force up to February 2018, when the Assembly of Kosovo adopted a new Law on Property Tax (LAW Nr. 06/L-005).

Those obliged to pay property tax: The responsible person for property tax payment is the owner of property. If the owner of property cannot be designated or cannot be found, the taxpayer is the person who legally uses or keeps the immovable property. If the legal owner or user of immovable property cannot be designated, or it can be designated but has no access to immovable property, the taxpayer will be the person, which is the user of property. Such a decision does not give any ownership rights to the user. Three municipalities populated by Serb minority do not apply the property taxation. 
Taxation bases: Taxation of property is based on the "market value of the property", defined in the compliance assessment standards of evaluations of property. "Market value" means the price at which a buyer is willing to buy and a seller is willing to sell immovable property when neither is under any compulsion to act and there is no relationship between the parties through family ties, marriage, common ownership or business affiliation. The best indicator of market value is the actual price for which a property has recently been sold.

Tax rate: Tax rates are set by municipality assembles within parameters of $1 \%$ to $0.15 \%$ defined by central regulation for property taxes. These tax rates are defined every year by municipality assembles and within parameters defined by the central regulation. Moreover, these tax rates may change in accordance with property categories, zones, uses and other parameters. That is, rates of property taxations are calculated depending on prices per $\mathrm{m}^{2}$ of the property categories in Kosovo.

Property categories: According to the property law, property has been classified as: 1) Residential property - real state property which is used for residence, meaning houses and apartments), 2) Commercial property- a property used for commercial purposes, wholesale and retail purposes, recreational services etc., 3) Industrial property - a property used for production, processing, handling storage of the goods, plants, storage areas and other workshops, 4) agricultural property - land and buildings used for agricultural purposes, 5) Other properties. The land by previse regulation was excluded from taxation, but since 2019, by new regulation the land is include and taxation is applied to it.

Property excluded from property taxation: Regulation 2003/36 clearly defines properties, which are excluded from taxation. Excluded property taxation include: a) Properties of Kosovo institutions, b) Property used by foreign governments UN, KFOR, c) other non-profit organization (NGO) properties which are designed for public benefit, property of the religious institutions, categories belonging to social cases.

Property assessment: Is carried out by municipalities based on the administrative instructions, which are issued at the central level. Municipalities review and reassess market value of the property every third or fifth year. The Ministry of Finance with administrative instructions define assessment standards, which include relevant variables such as revenues produced by property, the cost of construction, location, area and the status of the property. These standards are based on an overall assessment, except in the specific cases for specific properties using the below criteria

a) Comparison method: This method is usually used for houses, apartments, shops and offices. The sales comparison approach to property valuation uses information on recent open-market sales prices. The aim is to understand how differences in the characteristics of sold property - use, size, location, quality of buildings, and so on 
influence their prices. This information is then used to estimate the properties being appraised ("subject" properties). Where there is a large number of recent sales of fairly similar properties, as is often the case with dwellings and may be the case with smaller office and retail properties, statistical techniques (such as multiple regression analysis) can be used to assign values to each measurable characteristic, and the valuation can be done with a fair degree of confidence. Where sales are infrequent or are spread over a broad territory and where properties tend to be distinctive, the sales comparison approach is both more difficult and less useful.

b) Cost method: This method is usually used for industrial properties. The cost approach to property valuation involves estimating and combining three components:

Value = replacement cost of improvements - accrued depreciation + land value. Replacement cost is what it would cost to replace the existing structures and other improvements with new construction of equivalent usefulness but not necessarily the same design and construction technologies and materials. Accrued depreciation is the loss in value due to physical depreciation, functional obsolescence, and economic obsolescence. Land value is what vacant land in the same location, area, shape, physical characteristics, and allowable uses would sell for in the open market.

c) Income method: This is usually used for rented properties: that is, offices and large market buildings. The income approach to property valuation involves estimating the future income stream that can be ascribed to the property over its remaining economic life and using a "discount rate" or rate-of-return on investments of comparable risk to "capitalize" the income stream into a present value as of the valuation date. The basic mathematical relationship is: Value $=$ income / rate .

Income is estimated as the rents from the subject property or comparable properties net of taxes, insurance, and operating costs and adjusted for expected occupancy rates. The income approach is theoretically preferred for the valuation of rented properties since it reflects the thinking of market participants.

Municipality responsibilities related to property taxation: Every municipality is responsible for the following functions related to the administration of property taxation, information management regarding property taxation, property assessment, preparation and issuance of invoices, collection and obligatory collection and review of administrative claims. Municipalities issue taxation invoices prior to 31 March of each fiscal year. Taxation invoices include the following information: data base identifier, the name of taxpayers, property address, the assessed value of the property, tax rate, and total taxable amount, date of issuance, place and method of payment of the taxation invoice and the right for claims procedure. The tax invoices are prepared in three languages (Albanian, Serbian and English) and their distribution is carried out by the municipal officers according to certain zones. The special computer program for the property tax is supported and prepared by the 
Swedish SIDA. Municipalities have the right to collect property tax as an own source revenue. The tax payment is carried out through commercial banks, functioning in the territory of the municipality.

Problems during implementation of the property taxation: The main challenges in the area of implementation of the property taxation include a lack of updated information from the cadastre, unclear definition of addresses, an insufficient number of assessors of property tax, difficulties for specific properties' taxation and a method for the calculation of amortisation. Municipalities have a responsibility to provide information and to communicate with taxpayers.

\section{Tax incidence analysis}

Below in Table 6, is a simplified step by step analysis of tax incidence, in terms of "formal" and "effective" incidence. First of all, the formal incidence is the immediate answer to the question "Who pays the tax ?"; second, the effective incidence includes the taxpayers' reactions to the tax and its consequences; third, the problem of tax evasion and avoidance measures the potential distortion of tax capacity, and fourth, changes in price level show significant effects on tax when progressive taxes are being levied in times of rapidly changing prices and monetary income.

Table 6. Tax incidence analysis

\begin{tabular}{|c|c|c|}
\hline Criteria & $\begin{array}{l}\text { Description of the } \\
\text { Criteria/indicators }\end{array}$ & Property Tax \\
\hline $\begin{array}{l}\text { Formal } \\
\text { incidence: Who } \\
\text { pays the tax? }\end{array}$ & $\begin{array}{l}\text { owners/tenants, local } \\
\text { residents/foreigners, } \\
\text { households/businesses }\end{array}$ & $\begin{array}{l}\text { The responsible person for property tax } \\
\text { payment is the owner of property. If the } \\
\text { owner of property cannot be designated } \\
\text { or cannot be found, the taxpayer is the } \\
\text { person who legally uses or keeps the } \\
\text { immovable property. }\end{array}$ \\
\hline \multicolumn{3}{|l|}{$\begin{array}{l}\text { Effective } \\
\text { incidence: }\end{array}$} \\
\hline \multicolumn{3}{|l|}{$\begin{array}{l}\text { A) Economic } \\
\text { analysis }\end{array}$} \\
\hline \multicolumn{3}{|l|}{ - Efficiency } \\
\hline by scale (yields) & $\begin{array}{l}\text { the yields of tax revenue } \\
\text { and share of collected tax } \\
\text { in the total local revenues }\end{array}$ & $\begin{array}{l}\text { The participation of property taxation in } \\
\text { overall revenues of the municipalities, } \\
\text { for year } 2019 \text { is over } 6.4 \% \text {. }\end{array}$ \\
\hline $\begin{array}{l}\text { by distortion of } \\
\text { local economy }\end{array}$ & $\begin{array}{l}\text { people/businesses move } \\
\text { from the jurisdiction }\end{array}$ & $\begin{array}{l}\text { There are no frequent movements by } \\
\text { jurisdiction. }\end{array}$ \\
\hline - Equity/Fairness & $\begin{array}{l}\text { measured by the } \\
\text { exemptions }\end{array}$ & $\begin{array}{l}\text { The regulation of the property taxation, } \\
\text { excludes a small number of the tax } \\
\text { payers. }\end{array}$ \\
\hline
\end{tabular}




\begin{tabular}{|c|c|c|}
\hline by horizontal & $\begin{array}{l}\text { exemption applies to all } \\
\text { taxpayers }\end{array}$ & $\begin{array}{l}\text { The participation of exemptetion in } \\
\text { overall revenues is approximately } 0.4 \% \text { - } \\
0.9 \% \text {. }\end{array}$ \\
\hline by vertical & $\begin{array}{l}\text { exemptions applies to } \\
\text { same group of taxpayers } \\
\text { or progressive rating }\end{array}$ & $\begin{array}{l}\text { In some cases municipality assemblies } \\
\text { may decide to release from the taxes } \\
\text { cases of social categories. The property } \\
\text { tax law allows for a tax deduction of } \\
15,000 \text { euros for residential properties, } \\
\text { which allows substantial tax deductions } \\
\text { on the property. }\end{array}$ \\
\hline \multicolumn{3}{|l|}{$\begin{array}{l}\text { B) Financial } \\
\text { analysis }\end{array}$} \\
\hline - Limitation & $\begin{array}{l}\text { A self-limit is the number } \\
\text { of tax unit/taxpayers or } \\
\text { the size of tax object. } \\
\text { Limit by the law e.g. } \\
\text { regarding rating } \\
\text { (maximum rate, } \\
\text { minimum rate) }\end{array}$ & $\begin{array}{l}\text { The number of the property taxation } \\
\text { units is distributed in } 34 \text { units, } \\
\text { including here the division of property } \\
\text { taxation from MF. The total number of } \\
\text { the employees is } 165 \text {. The determined } \\
\text { limit for tax rates is from } 1 \% \text { to } 0.15 \%\end{array}$ \\
\hline - Flexibility & $\begin{array}{l}\text { The right to change the } \\
\text { rate setting, to install } \\
\text { exemption by LG }\end{array}$ & $\begin{array}{l}\text { The municipality keeps the right to } \\
\text { change tax rates every year, within the } \\
\text { limits, defined by central regulation. }\end{array}$ \\
\hline $\begin{array}{l}\text { - Avoidance, } \\
\text { tax evasion }\end{array}$ & $\begin{array}{l}\text { Taxpayers avoid and } \\
\text { evade paying tax } \\
\text { measured by rate of } \\
\text { collection } \\
\text { tax/collected tax) }\end{array}$ & $\begin{array}{l}\text { From overall planned revenues for year } \\
2017 \text {, over than } 105 \% \text {. The planed } \\
\text { revenue where } 22.2 \text { milion while have } \\
\text { been realized } 23.7 \text { milion. If compare } \\
\text { sum from tax invoice and from the } \\
\text { invoice of collected tax we can see that } \\
\text { approximately } 70 \% \text { is collected and } 30 \% \\
\text { is uncollected. }\end{array}$ \\
\hline - Reliability & $\begin{array}{l}\text { Difference of budgeted } \\
\text { and realized tax yields. If } \\
\text { the difference is large, it } \\
\text { is hard to estimate the tax } \\
\text { revenue for the next } \\
\text { years/periods (unstable } \\
\text { budgeting) }\end{array}$ & $\begin{array}{l}\text { Evidently problems there are on planning } \\
\text { of revenues from property taxes and as a } \\
\text { real parameter is taken revenues realized } \\
\text { in the previous year and based on that we } \\
\text { do planning. The difference is not such } \\
\text { high. }\end{array}$ \\
\hline - Volatility & $\begin{array}{l}\text { The change of tax yield } \\
\text { from each year to other. } \\
\text { If there are high waves } \\
\text { year to year, it is hard to } \\
\text { estimate the tax revenue } \\
\text { for the next years/periods } \\
\text { (unstable budgeting) }\end{array}$ & $\begin{array}{l}\text { Changes of the revenues from this } \\
\text { taxation is in linear proportion, } \\
\text { continuously we have a considerable } \\
\text { increase of the revenue collection, so by } \\
\text { years we have simobolic increase of the } \\
\text { revenue collection. }\end{array}$ \\
\hline
\end{tabular}




\begin{tabular}{|l|l|l|}
\hline - Elasticity & $\begin{array}{l}\text { How tax yields reflects to } \\
\text { the change of income of } \\
\text { taxpayers or the number } \\
\text { of tax payers? (income } \\
\text { elasticity, population } \\
\text { elasticity) }\end{array}$ & $\begin{array}{l}\text { The impact of revenues from property } \\
\text { taxation in overall revenues to tax payers } \\
\text { and their number which is very small, } \\
\text { particularly it is stressed that property tax } \\
\text { payers for residencies is small while } \\
\text { there is a considerable tax payers for } \\
\text { those who are carrying business or } \\
\text { industrial activity. }\end{array}$ \\
\hline $\begin{array}{c}\text { Cost of } \\
\text { administration }\end{array}$ & $\begin{array}{l}\text { What is the share of tax } \\
\text { administration costs in } \\
\text { the tax revenue }\end{array}$ & $\begin{array}{l}\text { Taking in to account overall revenues } \\
\text { from property taxes and number of the } \\
\text { employees in the tax administration and } \\
\text { cost participation is relatively high. An } \\
\text { additional cost is related to operation } \\
\text { costs, invoice issuance, information of } \\
\text { tax payers, obligatory collection, claims } \\
\text { procedures, information etc... }\end{array}$ \\
\hline
\end{tabular}

Source: Adopted from Ministry of Finance, Departament of Property Tax (2014-2019)

\section{Summary and recommendations}

OSRs are an inseparable part of the overall municipal budget. There is a need for municipalities to take strong and coordinated steps to improve the management and collection of OSR in general and property tax in particular, in order to increase of OSRs. Strengthening OSRs is a key issue for the functioning of Local selfGovernment and Fiscal Decentralization, which will impact on sustainable development of municipalities.

Property tax is considered a very important revenue for local finance; although there is a symbolic increase from year to year, and there are opportunities which are still untapped. Therefore, the municipalities in Kosovo should review these new opportunities which are related to a more advanced approach in managing the colection process of property tax revenues.

In our opinion, the priorities would be: a) Improvement of the cadastral maps, by which it would be easier to identify roads and properties, b) Improvement of the software for property tax and putting into the database those properties with a specific character, because their assessment is very complicated, c) To clearly define the calculation of property amortisation, the quality of objects and life of objects, e) To increase the awareness of citizens on the payment of taxes by continuous training of local officers on the functioning of the local taxation, particularly in issues related to property and their taxation, and f) Provide technical assistance to property tax officials in all municipalities.

Therefore we conclude that, the current situation and system in place leaves much to be desired and property taxes may have more potential as a revenue source for municipalities. 


\section{References:}

Asllani, G. 2010. Property Tax in Economies in Transition: Selected Case Studies. Property Tax in Kosovo. The Network of Institutes and Schools of Public Administration in Central and Eastern Europe. Bratislava: NISPAcee, 106-126.

Bird, R.M. and Slack, E. 1991. Financing Local Governments in OECD Countries: The Role of Taxes and User Charges. Local Government: An International Perspective.

Bird, R.M. 1993. Threading the Fiscal Labyrinth: Some Issues in Fiscal Decentralisation. National Tax Journal, 42(2), 207-227.

Blöchliger, H., Merk, O., Charbit, C. and Mizell, L. 2007. Fiscal Equalisation in OECD Countries. Paris: Economics Department, OECD.

Brown, K. and Hepworth, A. 2002. A Study of European Land Tax Systems. Working Paper of the Lincoln Institute of Land Policy. Available at http://www.lincolninst.edu.

Bryson, P.J. and Gary, C.C. 2003. Moral Hazard in Property Tax Administration: A Comparative Analysis of the Czech and Slovak Republics. Comparative Economic Studies, 45(1), 44-62.

Eckert, J.K., Gloudemans, R. and Almy, R. 1990. Property Appraisal and Assessment Administration. Chicago: International Association of Assessing Officers.

European Charter of Local Self-Government.1988. The European Council. EU.

Gloudemans, R.J. 1999. Mass Appraisal of Real Property. Chicago: International Association of Assessing Officers.

Holzman, R. 1992. Tax Reform in Countries in Transition: Central Policy Issues. Public Finance / Finances Publiques, 47(supplement), 233-255.

Kubátová, P. and Vítek, L. 1997. The Effectiveness of the Czech Tax System. Daňová politika: Teorie a Praxe.

Malme, J. 2000. The Legal and Administrative Framework for Market Value-Based Taxation of Immovable Property: Curriculum for Transitional Economies. Cambridge, Mass. Lincoln Institute of Land Policy.

Müller, A. 2001. Valuation. Available at http://www1.worldbank.org/publicsector/tax/valuation.html\#valuation.

Musgrave, R.A. and Musgrave, P.B. 1989. Public Finance in Theory and Practice. $5^{\text {th }}$ Edition. New York: McGraw-Hill.

Oates, W. 1999. Local Property Taxation: An Assessment. Land Lines, 11, 1-3.

Paweł, F. 2014. Theoretical Concepts of Property Tax: An Essential Source of Local Government Revenue in Europe, Vol. 36.

Sedmihradská, L. 2010. Property Tax in Economies in Transition: Selected Case Studies. Property Tax as a Key Tool for Fiscal Decentralisation: Unfulfilled Expectations in Central and Eastern European Countries, 7-16. NISP Acee.

Sevic, Z. 2006. Local Government Non-Tax Revenue Sources in Transition Countries: User Fees and Charges. Bratislava: NISPAcee.

Sevic, Z. 2005. Fiscal Decentralisation and Grant Transfers: A Critical Perspective. Bratislava: NISPAcee.

Spahn, P.B. 1997. Decentralised Government and Macroeconomic Control. Paper prepared for the International Institute of Public Finance, 53rd Congress, Kyoto, Japan.

Trasberg, V. 2004. Property and Land Taxation in the Baltic States. Journal of Property Tax Assessment and Administration, 1(2), 31-43.

Zodrow, R. and Mieszkowski, P. 1986. Pigou, Tiebout, property taxation, and the underprovision of local public goods. Journal of Urban Economics, 19(3), 356-370. 
Regulations:

Law No. 06/L-005 On Property Tax. Date: 01.10.2018.

Law No. 03/L-040 On Local Self - Government. Date: 20.02.2008.

Law No. 03/ L- 049 on Local Government Finance. Date: 13.03. 2008.

Law No. 06/L -133 Law On The Budget. 2018.

Law No. 03/L-048 On Public Financial Management and Accountability. 2008

Medium Term Expenditures Framework 2019-2021. April 2018.

Municipal Annual Tariff Regulations, Charges and Penalties.

Municipal Property Tax Regulations.

PISG - MEF. Administrative Instruction on Local Revenues No. 2007/2.

UNMIK Regulation No. 2000 / 45 on Self-Government of Municipalities in Kosovo, 11 August 2000.

UNMIK Regulation No. 2003 / 29 on Taxes on Immovable Property in Kosovo, 5 September 2003.

UNMIK Regulation No. 2007 / 30 on Self-Government of Municipalities of Kosovo, 16 October 2007. 